\title{
Main Andean sinistral shear along the Cooper Bay Dislocation Zone, South Georgia?
}

\author{
M.L. Curtis \\ British Antarctic Survey, Madingley Road, Cambridge CB3 0ET, UK (m.curtis@bas.ac.uk)
}

\begin{abstract}
The Cooper Bay Dislocation Zone (CBDZ) represents a major NW-SE trending tectonic boundary within the island of South Georgia that juxtaposes components of a Middle Jurassic to mid-Cretaceous island-arc and back-arcbasin system. New detailed structural data from the southern end of the dislocation zone reveal that earliest displacement along the boundary appears to have been associated with dip-slip reverse shear, characterised by widespread proto- to meso-mylonitic granitic rocks within the basement assemblage exposed to the southwest of the shear zone. Along the northeast margin, highly sheared and mylonitised metasedimentary and metabasic rocks reveal sinistral strike-slip kinematics and a sub-horizontal mineral lineation. Narrow zones of sinistral shear are locally superimposed within the basement rocks along the SW margin, that together with the presence of brittle sinistral faults suggest that the strike-slip component of deformation postdates the dip-slip. Comparison with the tectonic history of the Rocas Verdas Marginal Basin, Fuegian Andes, suggests that the sinistral shear event preserved along the CBDZ maybe be related to Late Cretaceous, main Andean orogenic transpression, although a Cenozoic event cannot to ruled out.
\end{abstract}

Citation: Curtis, M.L. (2007), Main Andean sinistral shear along the Cooper Bay Dislocation Zone, South Georgia?, in Antarctica: A Keystone in a Changing World - Online Proceedings of the $10^{\text {th }}$ ISAES, edited by A.K. Cooper and C.R. Raymond et al., USGS Open-File Report 2007-xxx,yyy,14, doi: 10.3133zzzzzz

\section{Introduction}

The island of South Georgia represents the emergent part of an isolated microcontinental block (fig. 1) that exposes the tectonically juxtaposed components of a Middle Jurassic to mid-Cretaceous island-arc and backarc-basin system (Macdonald et al., 1987). Palinspastic reconstructions correlate the Early Cretaceous back-arc basin deposits of South Georgia with those of the Rocas Verdes Marginal Basin (RVMB) in southernmost Patagonia along the former southwestern margin of Gondwana (Dalziel et al., 1975). Following closure and deformation of the RVMB during the main Andean orogeny, the South Georgia microcontinental block became tectonically displaced along the North Scotia Ridge during Cenozoic evolution of the Scotia Sea (Diraison et al., 2000; Livermore et al. 2007).

In this contribution I present a new kinematic interpretation of the Cooper Bay Dislocation Zone, an important regional shear zone cutting through southern South Georgia, that had previously been identified as possessing a complex tectonic history (Stone, 1982; Storey, 1983). Potential tectonic correlations with regional events are discussed.

\section{Geology and stratigraphy of South Georgia}

The south-western tip of South Georgia is characterised by a complex assemblage of highly deformed, pre-Middle Jurassic paragneisses and metasedimentary rocks that are intruded by extensive tholeiitic plutons (Drygalski Fjord Complex), together with the local development of mafic crust (Larsen Harbour Complex). This basement assemblage is interpreted as a Gondwana margin accretionary complex that underwent crustal thinning during Middle to Late
Jurassic times (Storey, 1983; Macdonald et al., 1987, Mukasa \& Dalziel, 1996), and is inferred to underlie much of the island.

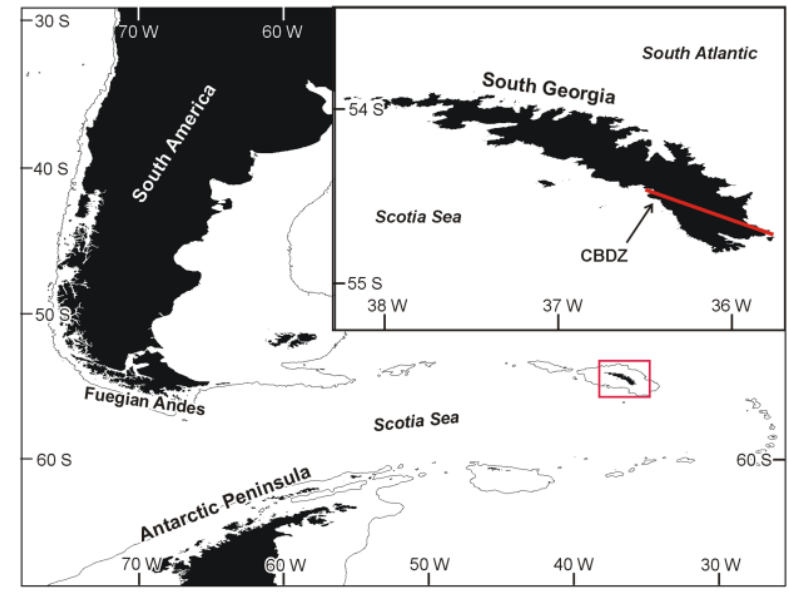

Figure 1. Location of South Georgia Island relative to the Scotia Arc, Antarctic Peninsula and southern Patagonia. Inset map of South Georgia showing the trace of the Cooper Bay Dislocation Zone (CBDZ).

The majority of the rock exposure on South Georgia is formed by two laterally equivalent turbidite sequences deposited in an Early Cretaceous back-arc basin: the volcaniclastic Cumberland Bay Fm. derived from a volcanic island arc, and the more siliciclastic Sandebugten Fm. that was derived from the Gondwana margin (Dalziel, 1975; Stone, 1980; Thomson et al., 1982; Tanner, 1987; Macdonald et al., 1987). A third metasedimentary succession, the Cooper Bay Formation, is exposed in the southeastern promontory of South Georgia and is considered to be a facies variant of 
the Cumberland Bay and Sandebugten formations (Stone, 1982).

Correlations with the RVMB of southern Patagonia suggest that the Early Cretaceous back-arc basin was deformed and uplifted during the mid-Late Cretaceous main Andean orogeny (e.g. Dalziel et al., 1975; Bruhn and Dalziel, 1977; Cunningham, 1995) with the basin fill deposits becoming juxtaposed against the basement complexes along a major tectonic boundary, referred to as the Cooper Bay Dislocation Zone (CBDZ) (fig. 1). The CBDZ encompasses an elongate belt of generally highly strained igneous and metasedimentary rocks. Along the southwest flank of the CBDZ, basic plutons and metasedimentary rocks of the Drygalski Fjord Complex are intruded by foliated sheets of porphyritic granites (Storey, 1983), while the northeast flank is characterised by highly deformed metasedimentary and metabasic rocks of the Cooper Bay Formation. Previous geological studies conducted in the 1970s revealed that the dislocation zone has a complex tectonic history displaying both dip-slip and strike-slip mineral lineations (Stone, 1982; Storey, 1983), although a major component of vertical, north-easterly directed reverse displacement was proposed to account for the stratigraphical juxtaposition (Storey, 1983; Macdonald et al., 1987). Tanner (1982) noted that the CBDZ truncates major structural boundaries within the basement.

\section{Structure and kinematics of the Cooper Bay Dislocation Zone}

The tectonic contact between the basement and metasedimentary units is not exposed, although its location was constrained at two localities to within 80$90 \mathrm{~m}$. Due to the lithological and structural differences encountered either side of this steep tectonic contact, the northeastern and southwestern margins of the CBDZ will be described separately.

\section{Northeast margin}

From its tectonic contact with the Drygalski Fjord Complex, the Cooper Bay Fm. exhibits between 250$700 \mathrm{~m}$ wide zone of shear, with pale-green, white and black, banded mylonite, giving way to highly deformed schists displaying a pronounced mineral lineation along the foliation plane. The margin of the shear zone was determined from where typical compositional banding within the metasedimentary rocks was identifiable. The mylonitic foliation and colour variation is defined by alternating epidote group- and quartz-rich bands. In lower strain rocks, epidote, zoisite and clinozoisite often form bands within a schistosity formed by actinolite/tremolite and chlorite. Quartz is generally present as thin, discontinuous mylonitic seams. Metabasic units display relict ophitic intergrowths of augite and plagioclase, together with epidote group minerals and chlorite.
The mylonite foliation has a mean orientation of $125 / 72^{\circ} \mathrm{SW}$, and displays a pronounced, strike-parallel mineral lineation (fig. 2) that has a mean orientation of $127 / 06^{\circ}$. Numerous shear bands ( $C^{\prime}$ planes) and asymmetric ' $\mathrm{S}$ ' folds indicate a sinistral sense of shear. The mylonite foliation is commonly folded by smallscale $(<1$ metre) folds, that define two fold generations: an early fold generation whose axial planes are parallel to the mylonite foliation with hinge lines parallel to the main mineral lineation along the foliation, and a second set of folds that clearly fold the mylonite foliation.

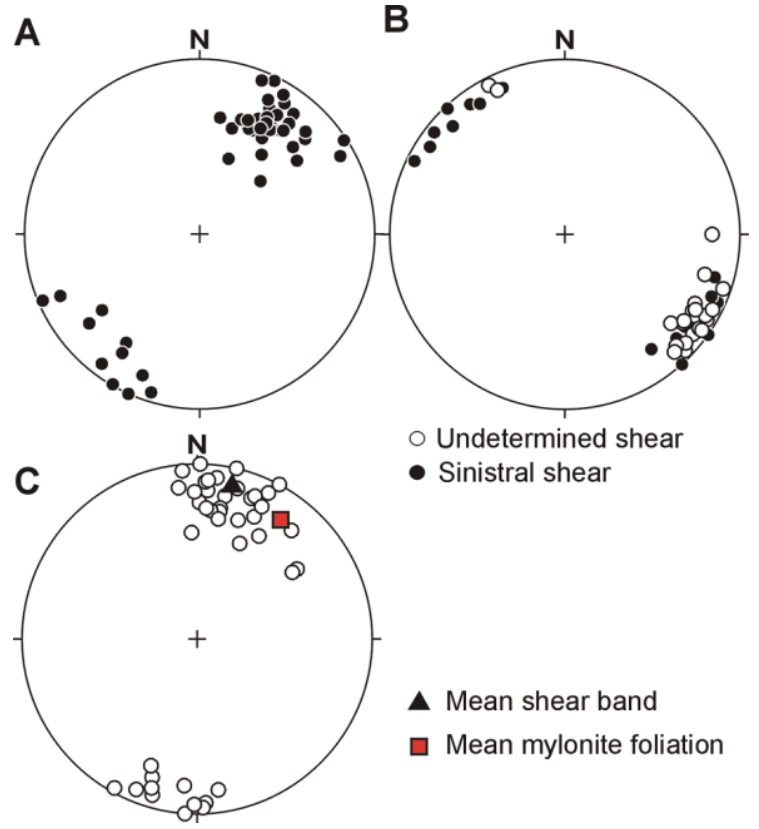

Figure 2. Structural data from the NE margin of the Cooper Bay Dislocation Zone. A) poles to mylonitic foliation, B) mineral lineations on mylonite surface, C) poles to sinistral shear bands.

The early generation folds are predominantly isoclinal or tight, upright to steeply inclined, with subhorizontal fold axes. In general these early folds are difficult to see due to their small interlimb angle and the common homogeneity of the mylonite. However, where identified, they are defined by bands of differing colour, which may represent an early formed mylonite foliation subsequently deformed and folded during progressive shear.

The younger ' $F_{2}$ ' folds are less tightly folded than the early generation folds, ranging from tight to open, and are predominantly upright or steeply inclined. However, fold axes vary greatly from gently plunging to sub vertical. There is a noticeable correlation between fold geometry and increasing fold plunge, with ' $S$ 'geometry folds completely dominating the steeply plunging to vertical fold population, whereas ' $M$ ' and ' $Z$ ' folds are present in the moderate to gently plunging fold population. This divergence in fold geometry distribution suggests that folding about moderate to 
gentle fold axes may be a product of buckling and the development of parasitic folds, whereas, the steeply plunging to vertical folds are possibly a product of distributed non-coaxial shear, in this case, sinistral shear.

\section{Southwest margin}

The southwestern margin of the CBDZ exposes the lithologically heterogeneous Drygalski Fjord Complex. At the southeastern end of the CBDZ, extensive coastal exposures of gabbro and diorite are heterogeneously sheared into CBDZ parallel zones displaying augen-, proto- and meso-mylonite textures, typically up to $130 \mathrm{~m}$ wide. In general, the mylonites developed within the basic plutons do not possess a pronounced mineral lineation. However, where present the lineation is predominantly down dip.

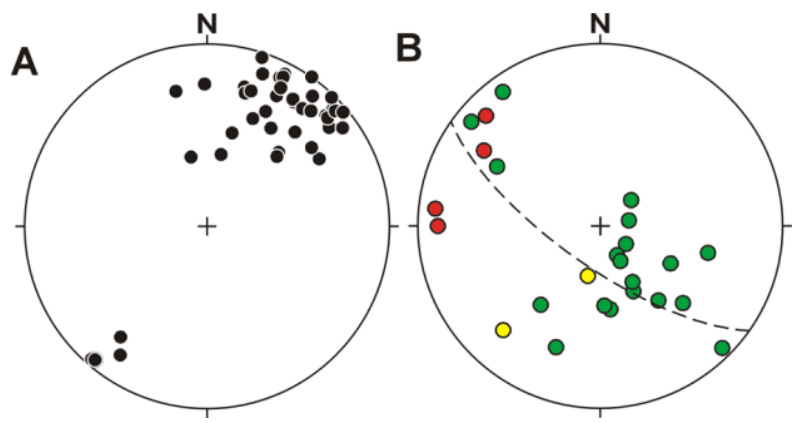

Figure 3. Structural data from southwest margin of the Cooper Bay Dislocation Zone. A) poles to mylonitic foliation, B) mineral lineation, red - sinistral, yellow reverse, green - unknown

The mountain ridges forming the south-western flank of the Quensel to Leward glaciers expose multiple sheets of porphyritic granite that intrude the Drygalski Fjord Complex. The granite sheets vary from a metre to several metres in thickness and are generally medium grained with porphyritic feldspar phenocrysts up to $15 \mathrm{~mm}$ in length. Protomylonite textures dominate the granite sheets, with even the lowest strain granites displaying lozenge shaped quartz and kinked biotite crystals. Rarely, narrow $(<1 \mathrm{~m})$ zones of meso- to ultramylonite are encountered. In general, mineral lineations are not well developed within the deformed granite sheets, although both dip-slip and strike-slip lineations were recorded (fig. 3). Dip-slip lineations predominate in the deformed granite sheets, but only two localities displayed unambiguous kinematic evidence, with both shear bands and $\sigma$-porphyroclasts indicating a reverse sense of shear.

Evidence for sinistral strike-slip shear was found at several localities along the southwest margin of the CBDZ. Typically, thin bands of metabasic schists, formerly dykes, display well-developed sinistral $\mathrm{S} / \mathrm{C}$ fabrics. In addition to the exploitation of zones of rheological contrast or weakness, several thin $(<20 \mathrm{~cm}$ wide) mylonite zones displaying a sinistral sigmoidal fabric were encountered cutting a porphyritic granite exposed in an unnamed peak at the northeast end of the Leward Glacier. The preservation of strike-slip shear strains along zones of rheological weakness within a domain otherwise dominated by widespread dip-slip shear suggests that sinistral shear post-dated reverse shear along the CBDZ.

\section{Brittle structures}

Thirty-one brittle faults where encountered, all possessing narrow damage zones characterised by fault breccia and protocataclasite, and where discernible fault, offsets varied between $3 \mathrm{~cm}$ and $12 \mathrm{~m}$. $83 \%$ of the fault planes strike about a NW-SE trend sub-parallel to the Cooper Bay Dislocation Zone (Fig. 4), and where shear sense was determined on 16 faults all were sinistral. A subordinate set of ENE-WSW trending, strike-slip faults are also present, which based on two of the faults appear to have a sinistral sense of displacement.

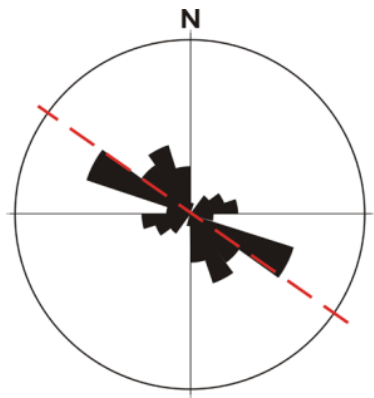

Figure 4. Rose diagram of mesoscale fault plane trends located within the Cooper Bay Dislocation Zone.

Dashed red line - mean trend of CBDZ.

The brittle fault population is widely distributed across the extent of the CBDZ in areas displaying evidence for sinistral ductile shear (northeast margin) as well as superimposed on the predominantly down-dip kinematics of the southwestern margin. The dominance of sinistral brittle structures throughout the CBDZ suggests that sinistral displacement along the dislocation zone was contemporaneous with the uplift of the South Georgia microcontinental block from biotite grade of the greenschist facies (Storey, 1983) into the brittle deformation regime.

\section{Correlation of sinistral shear with regional tectonic evolution}

Although a detailed structural analysis of the Cooper Bay Dislocation Zone has identified both the kinematics and relative chronology of shear events, the current absence of radiometric age control on these kinematic events means the regional tectonic implications for South Georgia remains speculative and relies on comparison with tectonic history of the Fuegian Andes, the E-W trending sector of the Patagonian orocline.

Sinistral strike-slip deformation has played an important role in the tectonic evolution of the E-W trending Fuegian Andes from the Late Cretaceous to 
Recent. At a regional scale, comparison of structural trends within the external arc of the Fuegian Andes and South Georgia reveals that sinistral strike-slip faults and shear zones truncate the main structural trend lines (Chiglione and Cristallini, 2007; Tanner, 1982). Some of these structural trends were established during the mid-Late Cretaceous main Andean Orogeny, which resulted in the closure and inversion of the RVMB. In the Cordillera Darwin (Fuegian Andes), main Andean deformation was characterised by sinistral transpressional deformation with the strike-slip component being partitioned along the Beagle Channel (Cunningham, 1995).

Sinistral transpressional deformation is inferred to have continued into the early Paleogene (Cunningham, 1993), with sinistral wrenching recognised from EarlyLate Eocene (Chiglione and Ramos, 2005; Chiglione and Cristallini, 2007; Olivero and Martinioni, 2001), becoming transtensional from the Early to midOligocene (Klepeis and Austin, 1997; Cunningham, 1993). Present day earthquake focal mechanisms are strike-slip (Forsyth, 1975).

The sinistral shear event along the CBDZ appears to have coincided with peak metamorphism in South Georia (lower greenschist facies) and continued during uplift into the brittle deformation regime. These basic observations appear to correlate with the main Andean orogenic deformation recorded within Cordillera Darwin (Cunningham, 1995), although it remains to be established how the sinistral event along the CBDZ relates to the wider structural history of South Georgia, in particular, if it is related to a transpressional, wrench or transtensional event. Although a main Andean orogenic event is favoured, the prolonged history of sinistral deformation within the evolving Fuegian Andes region cannot preclude a younger Cenozoic age.

\section{Summary}

New structural and kinematic data from the CBDZ of South Georgia reveal that sinistral shear post-dated reverse shear along this regionally significant tectonic boundary. Similarities between large-scale structural relationships and the style of deformation between South Georgia and the Fuegian Andes, in particular the Cordillera Darwin, suggest sinistral displacement along the CBDZ may correlate with main Andean sinistral transpressional deformation (Cunningham, 1995), although further structural and geochronological studies are required to confirm this

\section{References}

Chiglione, A.C., and Cristallini, E.O., (2007), Have the southernmost Andes been curved since Late Cretaceous time? An analog test for the Patagonia Orocline, Geology, 35, 13-16.
Chiglione, A.C., and Ramos, V.A., (2005), Progression of deformation and sedimentation in the southernmost Andes, Tectonophysics, 405, 25-46.

Cunningham, W.D., (1993), Strike-slip faults in the southernmost Andes and development of the Patagonian Orocline, Tectonics, 12, $169-186$

Cunningham, W.D., (1995), Orogenesis at the southern tip of the Americas: the structural evolution of the Cordillera Darwin metamorphic complex, southernmost Chile, Tectonophysics, 244, 197-229

Cunningham, W.D., Dalziel, I.W.D., Lee, T.-Y., Lawver, L.A., (1995). Southernmost South America-Antarctic Peninsula relative plate motions since $84 \mathrm{Ma}$ : implications for the tectonic evolution of the Scotia Arc region. Journal of Geophysical Research, 100, $8257-8266$.

Cunningham, W.D., Klepeis, K.A., Gose, W.A., Dalziel, I.W.D., 1991. The Patagonian Orocline: New paleomagnetic data from the Andean magmatic arc in Tierra del Fuego, Chile. Journal of Geophysical Research, 96, 16061-16067.

Dalziel, I.W.D., Dott, R.H., Winn, R.D. and Bruhn, R.L., (1975), Tectonic relations of South Georgia Island to the southernmost Andes, Geological Society of America, Bulletin, 86, 1034-1040.

Diraison, M., Cobbold, P.R., Gapais, D., Rossello, E.A., and Le Corre, C., (2000), Cenozoic crustal thickening, wrenching and rifting in the foothills of the southernmost Andes, Tectonophysics, 316, 91119 .

Forsyth, D.W., (1975), Fault plane solutions and tectonics of the South Atlantic and Scotia Sea, Journal of Geophysical Research, $80,1429-1443$.

Livermore, R., Hillenbrand, C-D., Meredith, M., and Eagles, G. (2007), Drake passage and Cenozoic climate: An open and shut case?, Geochem. Geophys. Geosyst, 8, Q01005, doi: $10.1029 / 2005 \mathrm{GC} 001224$

Macdonald, D.I.M., Storey, B.C., and Thomson, J.W., (1987), South Georgia, BAS GEOMAP Series, Sheet 1, 1:250,000, Geological map and supplementary text, 63 pp., Cambridge, British Antarctic Survey.

Mukasa, S.B., and Dalziel, I.W.D., (1996), Southermost Andes and South Georgia Island, North Scotia Ridge: Zircon U-Pb and muscovite ${ }^{40} \mathrm{Ar}{ }^{39} \mathrm{Ar}$ age constraints on tectonic evolution of Southwestern Gondwanaland, Journal of South American Earth Sciences, 9, 349-365.

Olivero, E.B., and Martinioni, D.R., (2001), A review of the geology of the Argentinian Fuegian Andes, Journal of South American Earth Sciences, 14, 175-188.

Stone, P., (1982), Geological observations in the Cooper Bay - Wirik Bay area, South Georgia, British Antarctic Survey Bulletin, 36, 129-131.

Storey, B.C., (1983), The geology of South Georgia: V. Drygalski Fjord Complex, British Antarctic Survey Scientific Reports, 107, $88 \mathrm{pp}$

Tanner, P.W.G., (1982), Geological evolution of South Georgia, in Antarctic Geoscience, edited by C. Craddock, pp.167-176, Madison, University of Wisconsin Press.

Thomson, M.R.A., Tanner, P.W.G., and Rex, D.C., (1982), Fossil and radiometric evidence for ages of deposition andmetamorphism of the sedimentary sequences on South Georgia, in Antarctic Geoscience, edited by C. Craddock, pp.177-184, Madison, University of Wisconsin Press. 